\title{
THE FRAGMENTATION OF POLITICAL REPRESENTATION AT MUNICIPAL LEVEL IN SLOVAK REPUBLIC IN PERIOD 2002 - 2018
}

\section{${ }^{\mathrm{a} M A R T I N}$ KLUS, ${ }^{\mathrm{b}}$ MARCEL MARTINKOVIČ}

Department of Political Sciences, Faculty of Philosophy, Universitas Tyrnaviensis in Trnava, Hornopotočná 23, 91843 Trnava, Slovak Republic

email: ${ }^{a}$ martin.klus@truni.sk, ${ }^{b}$ marcel.martinkovic@truni.sk

This paper is an outcome of the VEGA scientific project No. VEGA 1/0131/18 entitled Europe in Movement. Multicausality of Present Democracy Crisis and the Rise of Extremism in Europe.

Abstract: Presented study sheds light on the developments of political representation at municipal level and tries to identify the sources of its fragmentation. These sources are vested in electoral laws, in development of national party system and in public distrust towards partisan candidates including changes in decision-making dynamics of the electorate. All mentioned factors shape the popular preference to support of the electorate. All mentioned factors shape the popular preference to support
independent candidates in achieving municipal offices. This phenomenon gained on independent candidates in achieving municipal offices. This phenomenon gained on intensity between 2002 and 2018. The trend of ever-increasing support for civic and non-partisan candidates also introduces practical implications and risks in terms of lacking effective governing, transparency and of municipal policy control. Factors such as. non-existence of integrative organizational basis for political decision making, low levels of civie skills or elusive ownership structure of regional media. Most importantly, it is the inability of established political parties to maintain the functionality of democratic institutions in terms of public administration. All these factors increase the risks of decision-making at municipal level. Such development is part of deepening crisis of trust in political parties and leads to risks of forming a defect democracy.

Keywords: fragmentation of party system, municipal representation, effectivity of rule, independent candidates, local elections, political parties

\section{Introduction}

Decentralization of municipal structures together with expansion of their competences present an important aspect in transformation, consolidation but also in research of liberaldemocratic institutions. Thanks to competence transfer from central state bodies to municipal institutions citizen participation in public affairs, transparency and decision-making control of municipal representatives increases. Enhanced decentralization of public administration within Slovak political system under Mikuláš Dzurinda-led ruling coalitions (1998 - 2002 and $2002-$ 2004 respectively) aimed to form a framework for a more effective and transparent municipal governing. Efforts of the reform-oriented $1^{\text {st }}$ government of Mikuláš Dzurinda (SDK, SDL, SMK, SOP) followed up on the changes in territorialadministrative structure of Slovakia introduced by earlier Mečiar-led governments.

Thirty years since first efforts to decentralize Slovak public administration the research in this field within Central Europe focuses on analysis of chosen political aspects of competence transfer from the central authority to local governments. Among these we can include the issue of transparency and effectivity of governance, municipal modernization (Klimovsky, Pinterič, Jüptner 2016; Buleca, Mura 2014; Cseh Papp et al. 2018), limitation of participation (Klimovsky, Pinterič, Šaparniené 2016), legitimacy of municipal institutions (Hanáčková, Bumbalová, 2016), but also the research of political culture and aspects of forming communal representation. Within the context of lastly mentioned phenomenon, the relation between functioning of municipal effectivity and the extent of fragmentation of political representation is also being researched (Haydanka 2018). In connection to this, we can observe that with increasing agglomeration size, the functionality of local policymaking, based on of face to face principle, decreases. Environment defined by decline of mutual knowability between citizens renders their decisions dependent on external factors. If political parties and their candidates, in such environment of communal politics, do not have broad public support, then public electoral decision-making becomes influenced by regional and local interest groups, media and social media. Lower effectivity of institutions can become, relatively to maturity of civic society, the negative outcome of mentioned factors' influence. This is also being observed with institutions on national level. Both the decrease in effectivity and increase in corrupt practices lower civic trust in political parties. Discontent with the functioning of political system manifests in decrease of credibility of liberaldemocratic institutions (Gyárfášová 2015; Mura, Machyniak 2014), and in increase in extremist actors. This situation was confirmed by analysis carried out in V4 countries that acknowledged the historically ever highest distrust of Slovak citizens in political parties and institutions of representative democracy (Bútorová, Z., Mesežnikov, G. et al. 2017). Reasoning behind this development dwells not only in party centralization, but also in insufficient control and nontransparent financing of political parties. This leads to interweaving of political elites with chosen economic interest groups on national level. Increasing blurriness of interests at local level and declining turnout in municipal elections are part of this trend. The turnout continually dropped from $63.75 \%$ of eligible voters in 1990 to $48.67 \%$ in 2018 . Trend of decreasing civic participation in municipal elections makes the questions on elected candidates' legitimacy more important. In 2018 there were 2919 municipal parliaments and mayors elected. Based on this figure we can close that intensive decentralization took place in Slovakia since 1990. Such decentralization complicates development of small municipalities due to scarcity of resources to cover multiplicity of legit duties in areas such as: education, social services, transportation, waste disposal, environment, etc. Therefore, analyses on pros and cons of possible municipal mergers are conducted on expert level (Klobučník, Bačík, Matiašová, Fila 2018).

\section{Material and methods}

The aim of proposed study is to shed light on development of political representation at Slovak municipal level. This issue is deliberated in academia due to the success of non-partisan candidates. Based on this, our research field is divided into smaller sections. The main goal is to characterize the development of trends in political participation by analysis of statistical data in last five municipal elections. In order to do so, we have to tap into the relation between national electoral rules, including the party system byproduct, and the processes of selecting local representation. This is the second, partial, goal. Research design of this study is characterized by empirical data and background information vested in available primary and secondary sources. Secondary sources consist of domestic and foreign journal articles indexed in the Web of Science and Scopus databases. Primary sources are represented by data from Statistical Office of the Slovak Republic, and thus methodology consist also of quantitative research methods. Cluster, critical and comparative analysis are used with local electoral outcomes and annual reports of political parties in terms of their member base and functionality. These are fundamental for research in the field of political sciences, integral to social sciences, in comprehending the actions and evolution of political actors. Mentioned methods are supported by basic methodology in terms of abstraction, analysis, synthesis and comparison.

\subsection{Results and discussion}

The decentralization of local power structures carries another risk. The risk of fragmentation of political representation, which is described by increasing significance of non-partisan candidates (NEKA) for occupation of public offices. Such observed phenomenon is indirectly linked to issues within functioning of political parties at national level. The reasoning behind this that the established political parties in Slovak party system facing the decrease in public trust, which leads to their inability to integrate and include citizens into political life through their vertical organization. Their party membership dwindles or decreases as well. It can also manifest in their lowered functionality with regards to the assembly of candidate lists followed by decreasing public support. Such state of affairs has been present for several electoral periods. The characteristics 
of electoral system at local level pose another factor in favor of non-partisan candidates. Local and national electoral systems differ. General elections use proportional system with fixed party candidate list, where voters can assign maximum of four preferential votes to a political party in one, 150 mandates strong, constituency. Presence of just one electoral constituency lays foundation for a greater centralization of political parties.

At national level, this type of voting system was introduced by V. Mečiar's government (HZDS, SNS, ZRS) in 1998. Mečiar's cabinet has reduced four electoral districts into one, to fully exploit public popularity and charisma of its leader for electoral gains. This change of electoral system has had negative impact on development of Slovak system of political parties. Even today there are studies tackling outcomes of this change and discussing appropriate legislation changes to minimize the damage done (Kerekes, Pink, Šedo 2019). Consequences are seen in municipal, as well as regional elections. Electoral system at the nation-wide level has become an extreme pluralism model and inter-party competition can be described as polarized pluralism (Sartori 2005). This translates as competition between two blocks of political parties with occasional appearance of antisystematic party within Slovak context. Moreover, it forms bipolar opposition. Domination of eccentric tendencies among political parties, ideologically structured society and policy of triumph vested in populism, all cause polarization of party system. Tendencies towards atomization of electoral system in Slovakia have been present also in the latest general elections of 2016 , increasing the number of relevant parliamentary parties to eight. Low level of manifesto collaboration, strong interpersonal animosities among party leaders and the inability to create factions within party structures have led to continuing fragmentation and the rise of new political subjects. Ideological polarization rose also due to the entry of anti-systematic and extremist Kotleba - Ludová strana Naše Slovensko (K-LSNS) party into parliamentary politics in 2016 .

Compared to national level, municipal elections use first past the post system voting system for mayoral offices and semiproportional voting system for members of municipal councils. There is no unity with regards to used terminology for categorization of such hybrid voting system. It could be specified as unlimited vote system or block ballot. Such system ascribes to voters as many votes to assign, as there are mandates in their district. These are not cumulative (Chytilek, Šedo, Lebeda, Čaloud 2009). Municipal districts can be classified as multi-mandate in terms of municipal council elections. The required threshold to score a seat is defined by acquired eligible votes and by number of mandates for that particular district. For example, in district with seven seats, first seven candidates ranked highest by eligible votes acquired will get a mandate in municipal council. Voters can assign a minimum of one vote. Maximum reflects the number of mandates per district. Such specific voting system leads to creating mixed party coalitions at municipal level and multiple vectors of cooperation, which are ideologically not possible at national level. Higher number of constituencies, preference of persons over parties, non-existence of explicit quorum and non-utilization of quota in electoral number calculus, etc. shape municipal voting system. When there is no order randomization principle for candidate list present, along with low-level of voters' awareness and unfamiliarity with candidates, such factors can lead to trend in preferring candidates ranked high in the candidate list. Nowadays, candidate lists are ordered by alphabetical order. Research conducted at the level of regional authorities implies the risk of non-equality among particular candidates. The very place of a candidate in the list, especially at the start or at the end, can give unjustified advantage compared to other runners (Spáč, Voda, Zagrapan 2016). Albeit that parties form preelection coalitions, there is a rising and long-lasting trend in support of non-partisan (NEKA) candidates. This can lead to the risk of losing public control over decision-making done in municipal councils. Often the public does not know to whom that particular non-partisan candidate is linked to, who financed his or her campaign or whose interests will he or she follow.
3 The development of support for non-partisan candidates at municipal level

While looking at the success rate of non-partisan candidates in municipal elections in the period of 2002 - 2018 we can conclude the following. The success rate of non-partisan candidates in municipal council elections copies the development in occupation of mayoral offices. The difference is minimal. Success rate of non-partisan candidates in municipal councils is on the rise, with $2892(13.46 \%)$ seats in 2002, 3638 $(17.10 \%)$ seats in 2006, $4764(22.66 \%)$ seats in 2010. Municipal elections of 2014 brought 28,91\% support for non-partisan candidates, e.g. 6000 seats and in latest election of 2018 we saw an increase to $35.36 \%$ - 7301 seats in municipal assemblies. Based on mentioned data, the success and increase in support of non-partisan candidates are at the expense of partisan ones. Increasing almost by a tri-fold in the observed period. This has been enhanced by a trend observed prior 2014 municipal elections, when party candidates started to register and run as non-partisans to increase their chances and leave corruption scandals of established political parties behind. Similar trend occurred in mayoral elections. In 2002 non-partisan mayoral candidates took $951(32.66 \%)$ offices, with rare decrease to 895 $(30.83 \%)$ in 2006 and back on track increase to $979(33.67 \%)$ in 2010. Non-partisan mayoral candidates in 2014 elections scored $1104(37.95 \%)$ seats and $1323(42.42 \%)$ seats in 2018 .

3.1 The development of public support for KDH, SMK and SMK-MKP parties at municipal level from 2002 to 2018

The development of support towards party candidates at municipal level has different specifications. The study states only the gains of partisan candidates of established parliamentary parties, who ran in municipal elections without their party's support, e.g. outside of multicolored pre-election coalitions. Yes, for Slovakia it is also true that these heterogenous coalitions do not copy trends in cooperation at parliamentary level, but instead, they adapt to local context. Among parties with the oldest political tradition after 1989 we can include Christian Democratic Movement (KDH) and parties that represent Hungarian minority in Slovakia. The KDH party scored $157(5.4 \%)$ of all mayoral offices and $2350(11.38 \%)$ of all municipal councils' seats. This outcome was crucial for the party and its representative because it has been the first time since 2002 (13.52\% of all council representatives and $7.07 \%$ of all mayoral offices) when they managed to stop declining support at municipal level. The decline climaxed in 2014 (10.55\% of all council representatives and $4.19 \%$ of all mayoral offices) and signaled issues at national level as well. In 2016, for the first time since its formation in 1990, the party has not managed to be elected into National Council of the Slovak Republic.

Similar sine curve of development of voters' support at municipal level can be observed with ethnic party of Hungarian minority the Hungarian Coalition Party (SMK), later transformed to SMK-MKP. Hungarian minority parties transformed into one, the SMK, in 1998, due to legislative change disadvantageous to the formation of pre-election coalitions. SMK has not made it into parliament since 2010 due to party split and subsequent split in the electorate in 2009, accompanied with the departure of its leader Béla Bugár (cofounder of civic liberal subject Most-Híd). In 2018 municipal election the successor subject of SMK the SMK-MKP gained $115(3.96 \%)$ of all mayoral offices and $1248(6.04 \%)$ of all municipal councils' seats. Compared to results in 2014 the party managed to stop negative trend of declining support at local level at least. This trend became most visible, as in case of $\mathrm{KDH}$, after 2014 municipal elections. In Hungarian minority dominated southern districts of Slovakia the SMK-MKP managed to get only $107(3.67 \%)$ mayoral offices and 1151 (5.54\%) municipal councils' seats.

KDH, SMK-MKP and SNS also have experience with out-ofparliament existence. Their partisan history also documents the existential significance of stable and developed member base. 
The importance of developed local and regional structures manifests the most in situations when the party is not able to pass the $5 \%$ clause for entering the parliament. Vital member base, as in case of $\mathrm{KDH}$, which member base strength fell from 17814 in 2006 to 8948 in 2017, represents a factor that can, by proper utilization of local structures, lead to parliamentary comeback. In case of SMK-MKP the member base declined, also due to the split of electorate, from 11959 in 2006 to actual 9200 members, which is still above Slovak average and presents the party with an opportunity to establish and develop itself as an important regional actor.

\subsection{The development of public support for SMER Social Democracy and SNS parties at municipal level from 2002 to 2018}

Since 2004 the left part of Slovak political spectrum is being dominated by SMER-SD party. As the strongest coalition party, it has gained $592(20.38 \%)$ mayoral offices and 3692 (17.88\%) council seats in municipalities in 2018 municipal elections. Albeit having a significant gain of mandates at local level compared to other parties, the fact is that its position has declined since 2014. We can observe a visible drop, because SMER-SD had dominated the 2014 municipal elections with 847 $(29.11 \%)$ mayoral offices and $5123(24.68 \%)$ council seats across Slovakia. Since its founding in 1999, the of voters' support culminated historically in 2014 at municipal level. This success can be ascribed to personal nation-wide popularity of party leader and prime minister R. Fico. The party has established its dominance in Slovak party system after march 2012 and in spite of highly proportional voting system in general elections it was able to achieve a rare victory in terms of becoming the single ruling party. This advantage has been fully capitalized on in 2014 municipal election. Popularity of the party and its leader has had impact on development of members base as well. The highest number of members - 16869 - has been attained in 2010 and is slowly declining since then. Party progress report states 15182 registered members by December, $31^{\text {st }} 2017$.

Nevertheless, the party representation of SMER-SD in municipal councils rose between the years $2002-2014$ according to mandates gained at local level. The party gained 968 (4.5\%) mandates in 2002, in 2006 it was $4043(19 \%)$ mandates. The increasing trend continued also in 2010 with 4576 (21.76\%) mandates and culminated in 2014 with 5123 (24.68\%) mandates in municipal councils. Occupation of mayoral offices had a similar, increasing trend of support. In 2002 SMER-SD gained $68(2.33 \%)$ of mayoral offices, it swung to 419 (14.43\%) offices in 2006, followed by $599(20.6 \%)$ in 2010 . The party support at municipal level culminated in 2014 with $847(29.11 \%)$ of all mayoral offices in Slovakia.

The next member of coalition that has been formed after march 2016 general elections is Slovak National Party (SNS). The party has secured a better position and support in 2018 municipal elections compared to the one held in 2014. Trends of public support for this party at national and local level are opposite in comparison to SMER-SD. Multiplicity of corruption scandals by party's members and ministers during R. Fico's $1^{\text {st }}$ government in between years of 2006 and 2010, together with party infighting between party leader Ján Slota and 1st vicechairwoman led to party split and electorate split in 1999 and 2011. Leadership infighting in 1999 caused the removal of Ján Slota as party leader, with Anna Malíková becoming the new one. Consequently, Ján Slota founded a new party on January 6th, 2001, called Nová (New) SNS. The following dissipation of nationalist voters between two political subjects caused that both SNS and NSNS did not make it into national parliament. After their unification on April 30th, 2003 SNS became a parliamentary party again in 2006 general elections thanks to developed regional structures and sufficient member base (1 198 registered members in 2006). The party gained $11.73 \%$ of all eligible votes in 2006 general elections and entered coalition with SMER-SD and Vladimír Mačiar's L'S-HZDS. The situation in SNS leadership repeated in 2011. By that time Anna
Belosouvová (maiden name Malíková) left SNS with her supporters and founded $\mathrm{NaS}$ party. Again, this schism prevented both SNS and NaS to pass 5\% parliamentary threshold in 2012. With leadership change in 2010 and Andrej Denko becoming the party leader the stabilization and increase in member base came forth. Since 2012 the party's member base rose to 2335 registered members and hit 7662 members in 2018. Stabilization of member base brought results also at local level. In 2014 municipal elections, while not a parliamentary party, the SNS gained only $41(1.91 \%)$ mayoral offices and 841 (4.05\%) municipal councils' seats. However, in 2018 municipal elections municipal party representation rose to $160(5.5 \%)$ mayoral offices. Improvement was also visible in municipal councils with an increase to $1678(8.12 \%)$ seats. Leadership reshuffle of 2012 brought a new impulse that translated into member base and popularity increase, and enhanced the representation at local and national level. This claim is supported by party gains at municipal level in 2002 with $673(3.13 \%)$ council seats, with increase to $1169(5.49 \% \%)$ seats in 2006, with a drop to 938 $(4.46 \%)$ seats in 2010. Party support in acquisition of mayoral offices had a parallel, sine curve, development. In 2002 SNS gained $38(1.3 \%)$ mayoral offices, in 2006 it was $85(2.92 \%)$ with decline to 60 (2.06\%) offices in 2010. Comeback to former glory at municipal level of 2006 took place in 2018 municipal elections.

\subsection{The development of public support for Most-Híd, SaS} and OLaNO parties at municipal level from 2002 to 2018

Next party that is part of current coalition (SMER-SD, SNS, Most-Híd) formed at national level in 2016 is civic-liberal MostHíd party. The party formed due to ideological clash within the ethnically oriented Hungarian minority SMK party in 2009. Béla Bugár stepped down as long serving party leader of SMK and together with his followers (Zsolt Simon, Gábor Gál, László Sólymos, László Nagy and many others), including right-wing political elites such as: Rudolf Chmel, Ivan Švejna, Lucia Žitňanská and others, founded a new centrist political party based on civic principle. The party gained 127 (4.37\%) of all mayoral offices in 2018 municipal elections. With regards to municipal councils it managed to gain $915(4.43 \%)$ seats. Compared to election results of 2014 with 87 (2.99\%) mayoral mandates and just $829(3,99 \%)$, the party slightly improved its representation at local level on 2018. It was the best municipal election result ever since it has been founded in 2009 by splitting from SMK. Despite this fact, Most-Híd party has relatively low representation at municipal level in period of 2010 to 2018. In its first year of existence (2010) the party gained $908(4.31 \%)$ council seats and $95(3.26 \%)$ mayoral offices. Its municipal support had declined in next municipal election of 2014, which got mitigated by greater gain of mandates in 2018 .

Currently the strongest opposition party in the National Council of the Slovak Republic, is the Liberty and solidarity $(\mathrm{SaS})$ party, established in 2009 gained $7(0,24 \%)$ mayoral mandates and 110 $(0.53 \%)$ council seats. The party managed to increase its municipal representation by a minimal margin compared to 2014 municipal elections, with $5(0.17 \%)$ mayoral offices and 89 $(0.42 \%)$ council seats. However, it has managed to put a stop to the declining support at municipal level and slightly reach out to maximum of $20(0.68 \%)$ mayoral offices and $212(1 \%)$ council seats from 2010 municipal elections. Such results together with low number of members reflects party's cadre profile, its orientation towards national politics and ever-present disinterest of party leadership in forming vigorous local and regional structures. The party membership has fallen from historically highest number of 292 in 2012, due to departure of its members around Jozef Kollár, to 208 registered members in 2018. This fact and the fact that efforts for systematic development of local and regional structure is absent, could be one of the reasons for low municipal representation.

OL'aNO, founded in 2012, is another parliamentary subject in Slovak national politics. It has the character of non-standard, anti-establishment movement. Its leadership does not create regional structures on purpose. The whole movement centers and 
profiles itself around charismatic figures such as the leader Igor Matovič, Jozef Viskupič or Erika Jurínová. Since Igor Matovič presents the movement as group of politically independent citizens, the subject does not meet one of the important aspects of standard political party. The presence of a rigid party structure fundamental to forming party discipline. Movement membership, as a prerequisite for manifesto integrity, does not exist among most of

Ol'aNO candidates. Provisional member base has changed only slightly since 2012 . From 4 registered members back then to 13 in 2017. Therefore, the presented subject meets the criteria for anti-political and anti-establishment parties (Schedler 2002) that do accept democratic framework of political competition, but systematically question ability of established political parties to solve crucial societal issues. Today, the official name of the subject is OLaNO-NOVA due to acceptance of cooperation at national level with small party of $\mathrm{KDH}$ leavers centered around Daniel Lipšic and Jana Žitňanská. Their local representation reflects the non-engagement of the movement at local level. There are no successful candidates in 2014 municipal elections that would run independently, outside of pre-election coalitions. However, in 2018 municipal elections OL'aNO independent sympathizers gained $3(0.03 \%)$ mayoral offices and $84(0.4 \%)$ council seats. Based on this it seems that OLaNO has started to focus also to local level, not just national one. Nevertheless, their local representation, in terms of their sympathizers, is still small.

3.4 The development of public support for K- LS NS and SME RODINA - Boris Kollár parties at municipal level from 2002 to 2018

Contemporary opposition at national level also includes subjects as K-LS NS and SME RODINA - Boris Kollár, both founded in 2015. Both parties have entered parliament after the 2016 general elections. Ideologically inconsistent, centrist party of the entrepreneur Boris Kollár got therefore involved in municipal elections just in 2018. It has gained 11 (0.37) mayoral offices and $123(0.59)$ council seats. With the party being a freshman in Slovak politics, we cannot provide a more complex analysis. However, the party is working intensively with its member base, with 1350 registered members in 2017, which allows for future possibilities to establish itself at municipal level.

Last parliamentary party, which we have analyzed with regards to its development of political representation at municipal level, is the Kotleba - Our Slovakia people's party (K-LS NS). This extreme right-wing party is still a subject to dynamical development in communication strategy and self-presentation, while simultaneously being the very reason of polarization of party system in Slovakia. It can be described as hidden antisystem subject, which meets the ideological and relational antisystem attributes (Kubát, 2010). We will try to briefly account on its development, characterized by bottom-up creation. Marián Kotleba is the leader of extremist right-wing K-LS NS party. He managed to set up himself at national level in 2016 after multiple failed political projects. He and his closest colleagues and sympathizers of fascist Slovak state of 1939 - 1945 (Katuninec 2014) tried their luck in the first decade of 2000's with an organization listed as civic association and named Slovenská pospolitost' (Slovak Commonalty). This civic association got later transformed to a political party called Slovenská pospolitost' - Národná strana (Slovak Commonalty - National Party, SP - NS). SP - NS got abolished in March 2006 by the High Court of the Slovak Republic due to their manifesto being in defiance with The Slovak Constitution (Kupka, Laryš, Smolík 2009). Manifesto of current K-L'S NS, founded in November 2015 is just a more sophisticated alteration of its predecessor from 2006. Marián Kotleba, as independent runner, won the 2013 regional election and become the President of Banská Bystrica Self-Governing Region. This has become a key moment for his party in establishing itself at national level. He made it into second round of mentioned regional elections with, then used, absolute first past the post voting system. His ability to mobilize disgruntled voters as an independent candidate against his opponent, then incumbent, MEP Vladimír Maňka from
SMER - SD, brought him 71397 votes in the second round. His adversary gained only 57164 despite support from a broad coalition formed by SMER - SD, LS - HZDS, HZD, KDH, SMK - MKP, SZ and SMS. Such result could be ascribed to multitude of factors. In this context, specific regional aspects, such as: unemployment rate, ethnic structure of population, investments into infrastructure, etc. had influence on this specific preference of voters in Banská Bystrica Self-Governing Region (Buček, Plešivčák 2017). Taking into account the center / periphery cleavage in Slovak party system, we can close that these regional elections were also a form of public disapproval of decisions and régime of SMER - SD ruling party. The win of a candidate that did not hide his extreme political positions could be ascribed to non-partisan candidacy and popularity. This is also an example of how does party polarization, and civic disapproval of parliamentary parties, influence voters' decisions at municipal level. Cumulation of disgruntled and politicaly unidentified voters, high level of electoral volatility with the decisions done in segment of first- time voters - $22.7 \%$ in 2016 (Világi 2018) led to the rise of K-L'S NS and its leader, Marián Kotleba, into parliamentary politics in 2016. Multiple failures preceded conjunction of M. Kotleba's from regional politics, as independent runner, to national under the party's flag. In 2010 general elections his party gained only 33724 (1.33\%) votes, followed by $40460(1.58 \%)$ votes in 2012 snap elections. Mentioned regional elections of 2013 were the turning point, since voters elected Marián Kotleba as the President of Banská Bystrica Self-Governing Region. Despite the success in 2016 general elections, where the Kotleba - Ludová strana Naše Slovensko gained 209779 eligible votes, the gains in 2017 regional elections and 2018 municipal elections were minimal. Marián Kotleba has not defended his regional office in 2017. Majority of pro-democrat runners withdrew their candidacy earlier in favor of Ján Lunter, who was also a non-partisan candidate. The Slovak Government has changed the regional voting system from absolute to relative first past the post system for the President of Self-Governing Region office. K-LS NS did not gain any significant representation at regional and municipal level, despite the increase in their member base from 11 members in 2010 to 1439 members in 2017. They have gained just one regional council seat in Banská Bystrica Self-Governing Region (Marián Kotleba, K-LS NS Chairman) and one in Nitra Self-Governing Region (Milan Uhrík, K-L'S NS ViceChairman). Similar trend is present at municipal level. The party has gained just $1(0.03 \%)$ mayoral office and $42(0.20 \%)$ council seats in the 2018 municipal elections. However, the municipal representation has slightly improved compared to 2014 municipal elections, in where the party gained $33(0.15 \%)$ council seats.

\section{Conclusion}

We can observe an increasing tendency in fragmentation of representation at municipal level during the researched period of $2002-2018$. Type of municipal voting system and development of party system at local and national level are the cause of this trend. These main factors are enhanced by decline in voter's trust in political parties, which leads to increasing support for nonpartisan candidates. Centralization of political structures caused by voting legislation change passed before 1998 general elections impacts this trend as well. Due to introduction of one nation-wide candidate list political parties became more elitist. They are not forced to develop their local representation and activities in a systematic way. Instead, they get by with a handful of party elites at national, regional or district level. It seems that the bottom-up development of political structures past 1998 is absent. This is accompanied by party centralization and quantitatively limited member base. One could say that low level of regional presence is natural for newly established subjects, however, many parties that are present for 2 and more electoral periods did not make any significant progress in creating regional and local structures. If we compare contemporary opposition and coalition parties, we can conclude that the ruling coalition of SMER-SD, SNS and Most-Híd fares better in terms of developed member base. SMER-SD has, despite declining member base since 2012, the most members (15 182 registered 
members by December $\left.31^{\text {st }}, 2019\right)$. SNS has 7662 and Most-Híd has 5517 members. Thus, the ruling coalition exceeds all opposition parties in terms of member base strength altogether by multifold. This factor allows them for a more effective presence at municipal level that manifests in better municipal representation. The importance of developed local structures is documented by the split in SNS and SMK-MKP parties, and also by current experience of KDH. All mentioned subjects managed to survive their out-of-parliament period thanks to developed local structures that allowed for maintaining their influence at local level. However, the tendency of party weakening in Slovak party system continues due to absence of functionality procedures, such as party preliminaries or intra-party referendums.

Going back to trends in municipal representation we can conclude that voting participation has a sine curve character and oscillates around $48 \%$ threshold. Voter participation was at $49.51 \%$ in 2002 , declined to $47.65 \%$ in 2006 and increased back to $49.69 \%$ in 2010 . The 2014 municipal election brought a decrease in participation to $48.34 \%$. In recent 2018 municipal elections it has slightly increased to $48.67 \%$. Analysis of development in trends on municipal elections from 2002 to 2018 proves an increasing fragmentation of political representation, despite creation of various pre-election coalitions. The source of such atomization and a potential risk in observed trend is the ever-increasing representation of non-partisan candidates. Their share rose from $2924(13.46 \%)$ in 2002 to 2919 (35.36\%) municipal council seats in 2018. In terms of mayoral elections, the trend is similar with non-partisan candidates with an increase from $951(32.66 \%)$ mayoral offices in 2002 to $1232(42.42 \%)$ in 2018. Based on presented electoral gains we can conclude that their success is at the cost of partisan candidates. This prevents creation of functioning majorities within municipal council, since the mayor and municipal council are elected separately. We can see possible reasons for creation of often blocked councils also at the side of citizens, who lack political experience and skills in contrast to their ambition to participate in municipal decision-making. Increased popularity of non-partisan candidates does not go hand in hand with increase in political competence of municipal representation expressed as the ability to integrate and carry out common goals. This fact leads to lower effectivity of public control within atomized municipal representation. High level of trust in non-partisan candidates can also be related to failed personal policy within political parties. Failed personal policy is partly caused by limited by size of particular member base. These development trends lead to clientelist parliamentarism in national party system (Klíma 2015), defined by risk of party centralization and higher level of corruption and instability in execution of power. Out of all political parties, only SMER-SD managed to resist the trend of non-partisan candidates. Its support rose continually at municipal level until 2014. KDH, SNS, SMK-MKP and Most-Híd are far behind in terms of creating municipal representation success rate. The SMK-MKP party keeps a solid ground at municipal level thanks to broad member base even in spite of earlier infighting and split. Parliamentary parties: SME RODINA Boris Kollár, SaS, OLaNO-NOVA and K-L'S NS managed to make marginal gains, however their municipal representation is still below $2 \%$ of all allocated council seats. Fragmentation of political representation at municipal level hints that development of civic participation, in terms of functional political parties and movements, is fading away from Slovak party system. Political parties and movements still remain fundamental actors in linking decision-making processes at different levels, ranging from nation-wide civil service to regional and municipal level of public administration. Atomization in development of political representation pose political risks in terms of stability, effectiveness and decision-making transparency. The reasons are obvious. There is no legislation on lobbing, enforceable legislation on financing and functioning of political parties or legislation addressing conflict of interests between civil service, municipalities and private sector, 30 years after the regime change of 1989.

\section{Literature:}

1. Buček, J., Plešivčák, M.: Self-Government, Development and Political Extremism at the Regional Level: A Case Study from the Banská Bystrica Region in Slovakia. Sociológia, 2017, 49 (6), 599-635. ISSN $0049-1225$.

2. Buleca, J., Mura, L. Quantification of the efficiency of public administration by data envelopment analysis. Procedia Economics and Finance, 2014, 15, pp. 162-168.

3. Bútorová, Z., Mesežnikov, G. a kol. Aktivne občianstvo a občianska participácia na Slovensku a v krajinách V4 [online]. http://www.ivo.sk/buxus/docs//rozne/Prezentacia_IVO_19_12_ Aktivne_obcianstvo.pdf (access 10.03.2019).

4. Cseh Papp, I., Varga, E., Schwarczová L., Hajós, L. Public work in an international and Hungarian context. Central European Journal of Labour Law and Personnel Management, 2018, 1 (1), $6-16$

5. Chytilek, R., Šedo, J., Lebeda, T., Čaloud, D.: Volebni systémy. Praha: Portál, 2009, 375 p. ISBN 978-80-7367-548-6.

6. Gyárfášová, O.: To sladké slovo demokracia ...

Spokojnost' s demokraciou a politické odcudzenie na Slovensku. Sociológia，2015, 47 (4), 365-389. ISSN 0049 1225.

7. Haydanka, Y.: Political and party environment fragmentation at a regional level in the light of local elections in the Czech Republic. Tomsk State University Journal of Philosophy, Sociology and Political Science. 2018. (45), 184 - 193. ISSN: 2311-2395 [online]. [cit.2019-01-04]. Available: http://journals.t su.ru/philosophy/en/\&journal_page $=$ archive $\& i d=1770$

8. Hanáčková, D., Bumbalová, M. 2016. Innovations in selfgovernment. Acta Oeconomica Universitatis Selye 5 (2), 88 - 96 9. Katuninec, M.: Režim slovenského štátu a jeho vývojové konotácie. In: Fiamová, M., Hlavinka, J., Schvarc a kol. Slovenský štát 1939 - 1945: predstavy a realita. Bratislava, Historický ústav SAV, 2014, pp. 125-136. ISBN 978-80-89396-32-0.

10. Kerekes, D., Pink, M., Šedo, J.: Slovenské stranické zemětřesení 2016. Pomohla by malá volební reforma? .Sociológia, 2019, 51 (1), 64-83. ISSN 0049 - 1225.

11. Klimovsky, D., Pinterič, U., Jüptner, P.: Local Government Systems in Selected Post-Communist EU-Member Countries. Gestion y Politica Publica. 2016. (25) Issue: 1 203244. ISSN: 1405-1079.

12. Klimovsky, D., Pinterič, U., Šaparniené, D.: Human Limitations to Introduction of Smart Cities: Comparative Analysis From Two CEE Cities. Transylvanian Review of Administrative Sciences. 2016. (47), 80-96. ISSN 18422845. [online]. [cit.2019-08-04]. Available: http://rtsa.ro/tras/in dex. $\mathrm{php} /$ tras/article/view/473

13. Klíma, M.: Od totality k defektni demokracii. Praha: SLON, 2015. 364 p. ISBN 978-80-7419-139-8.

14. Klobučník, M., Bačík, V., Matiašová M., Fila R.: Negatívne aspekty zlučovania obcí $\mathrm{v}$ rámci komunálnych reforiem perspektíva na príklade Slovenskej republiky. Sociológia, 2018, 50 (4), 448-481. ISSN 0049 - 1225.

15. Kubát, M.: Politická opozice v teorii a středoevropské praxi. Praha: Dokorán, 2010. 199 p. ISBN 978-80-7363-285-4.

16. Kubka, P., Laryš, M., Smolík,J.: Krajni pravice ve vybraných zemích středni a východni Evropy. Brno: MPÚ, 2009. 268 p. ISBN 978-80-210-4845-4.

17.Ministerstvo vnútra SR, https://www.minv.sk/?vyrocnespra vyps (access 15.03.2019).

18. Mura, L., Machyniak, J. Ethical aspects of public administration. Hradec Economic Days 2014: Economic Development and Management of Regions, PT V, 2014, pp. 5965. ISBN 978-80-7435-370-3

19.Národná rada SR, https://www.nrsr.sk/web/?sid=fina ncne_spravy_stran (access 15.03.2019).

20. Sartori, G.: Strany a stranicke systémy. Brno: CDK, 2005. 466 p. ISBN 80-7325-062-4.

21. Schedler, A.: Elections Without Democracy. The Menu of Manipulation. Juornal of Democracy, 2002, 13 (2), 36-50 ISSN 1045-5736.

22. Spáć, P., Voda, P., Zagrapan, J.: Abeceda ako nástroj úspechu. Prípad regionálnych volieb na Slovensku. Sociológia, 2016), 48 (1), 71-90. ISSN 0049 - 1225. 
23. Štatistický úrad SR. Vol'by do orgánov samospráv obcí 2002. [online]. [cit.2019-08-04]. Available: http://volby.statistics. sk/oso/oso2002/sk/default.htm .

24 Štatistický úrad SR. Vol'by do orgánov samospráv obcí 2006. [online]. [cit.2019-08-04]. Available: http://volby.statistics.sk/ oso/oso2006/slov/index.jsp@ subp=v.htm .

25. Štatistický úrad SR. Vol'by do orgánov samospráv obcí 2010. [online]. [cit.2019-08-04]. Available: http://volby.statistics.s k/oso/oso2010/menu/indexv.jsp@lang=sk.htm .

26. Štatistický úrad SR. Vol'by do orgánov samosprávnych krajov 2013. [online]. [cit.2019-08-04]. Available: http://volby.st atistics.sk/osk/osk2013/VUC/osk_def_sk.html

27. Štatistický úrad SR. Vol'by do orgánov samospráv obcí 2014. [online]. [cit.2019-08-04]. Available: http://volby.statistics.sk/ oso/oso2014/oso2014/sk/data.html .

28. Štatistický úrad SR. Vol'by do orgánov samospráv obcí 2018.

[online]. [cit.2019-08-04]. Available on: http://volby.statistics .sk/oso/oso2018/sk/data01.html .

29. Világi, A. Prvovoliči vzrkadle volieb 2016: (dis)kontinuita vtrendoch voličského správania mladých l’udí? [online]. [cit.2019-04-03]. Available: http://www.prog.sav.sk/sites /default/files/2018-03/Prognosticke_prace_Prvovolici-1.pdf .

\section{Primary Paper Section: A}

Secondary Paper Section: AD 